\title{
They Helped Modernize Turkey's Medical Education and Practice: Refugees from Nazism 1933-1945*
}

Arnold Reisman

\section{Summary}

This paper discusses a dimly lit and largely unknown bit of 20th century history. Starting in 1933, Turkey reformed its medical health care system using invitees fleeing the Nazis and for whom America was out of reach because of restrictive immigration laws and wide-spread anti-Semitic hiring bias at its universities. Among the invitees were several medical scholars who played a large role in westernizing the new Turkish republic's medical practice and research as well as its school curricula.

Keywords: Jewish doctors under Nazism; history of medicine in Turkey; medical education

\section{Introduction}

Starting in 1933, the Nazis' plan to rid themselves of Jews beginning with intellectuals with Jewish roots or spouses became a windfall for Ataturk's determination to modernize Turkey. A select group of Germans with a record of leading-edge contributions to their respective disciplines was invited with Reichstag's backing to transform Turkey's higher education and the new Turkish state's entire infrastructure. This arrangement, occurring before the activation of death camps, served the Nazis' aim of making their universities, professions, and their arts judenrein, cleansed of Jewish influence and free from intelligentsia opposed to fascism. Because the Turks needed the help, Germany could use it as an exploitable chit on issues of Turkey's neutrality

* This paper is based on Arnold Reisman, Turkey's Modernization: Refugees from Nazism and Ataturk's Vision, New Academia Publishers (Washington DC 2006).

Arnold Reisman, PhD, PE, 18428 Parkland Drive, Shaker Heights, Ohio 44122, USA (arnoldreisman@sbcglobal.net). 
during wartime ${ }^{1}$. Thus, the national self-serving policies of two disparate governments served humanity's ends during the darkest years of the 20th century.

In July 1923, the Lausanne Treaty of Peace was signed and on October 29, the Republic of Turkey was proclaimed on a segment of the defunct Ottoman Empire. In short order "a sweeping of social reforms was implemented ... In 1924 the medreses (religious colleges), tekkes (dervish lodges), and zavies (dervish cells) were closed down. In 1927 religious education was abolished in all schools" ${ }^{2}$, and an edict required replacement of the Arabic script by a newly created Latin-based alphabet including a change of all public signage by $1928^{3}$.

Under Ataturk's leadership Turkey's new government was keenly aware that the medrese-based system of civilian higher education was woefully lacking compared to the education provided by western research universities. As its entire system of post-secondary education, the Republic inherited three to four hundred Ottoman vintage (Islamic) medreses ${ }^{4}$, the Dar-ül Fünun (house of knowledge), a fledgling state university teaching some western sciences based on the French university model, and three military academies. The system and its components needed to be redesigned if not replaced. Once all medreses were abolished, the country was left with the three military academies and the Dar-ül Fünun. The latter was transformed into the University of Istanbul, Istanbul Technical University was created from one of the military academies, and Ankara University was founded from the ground up.

The three universities were to be fashioned on the prevailing German university model. However, since qualified personnel were not readily available to do all this, they had to be "imported". On reflection, "in its essence, the affair that we call or understand as Atatürk's Üniversite Reformu was not merely a university reform, but the ultimate apex of the Atatürk cultural movement started in the years 1925 to $1926 " 5$.

Hitler's assuming power in Germany followed the creation of the Turkish Republic by no more than ten years after the end of its prolonged War of Independence. Passage of Germany's "Civil Service Law" a few weeks after the January 30, 1933 Nazi takeover created a window of opportunity for

1 The Bosporus and the Dardanelles held strategic importance. So did an uninterrupted supply of chromium and other scarce materials needed by Germany's munitions factories.

2 Bahadir/Danisman 2005, 290.

3 Williams 1929,94-108; offers 17 photos and an essay depicting the process of implementing the edict.

4 Ihsanoglu 2004.

5 Kazancigil/Ortaylı/Tanyeli 2000,119-132. 
Turkey. The law forced the departure of intellectuals with Jewish familial connectivity as they were all employed by the State.

Among those first fired was Hungarian-born Frankfurt pathologist, Dr. Philipp Schwartz. He quickly fled with his family to Switzerland. Schwartz's father-in-law was Professor Sinai Tschulok, who had taken refuge in Switzerland after the 1905 Russian Revolution and was a close friend of Albert Malche, a Swiss professor of pedagogy who in 1932 was invited to Turkey to prepare a report on the Turkish educational reform. His Rapport sur l'université d'Istanbul was submitted that year. Malche recognized a double opportunity of saving lives while helping Turkey and contacted Schwartz. In March 1933, Schwartz established the Notgemeinschaft Deutscher Wissenschaftler im Ausland (The Emergency Assistance Organization for German Scientists) to help persecuted German scholars secure employment in countries prepared to receive them 6 .

Predisposed to German science and culture and recognizing the opportunity that presented itself, Turkey invited Philipp Schwartz ${ }^{7}$ to Ankara. Schwartz brought with him a set of CVs from the Notgemeinschaft ${ }^{8}$ while Minister of Education Resit Galip arrived with a complete list of professorships that were vacant at Istanbul University ${ }^{9}$. Their mission was to select individuals with the highest academic credentials in disciplines and professions most needed in Turkey. After nine hours of negotiations, agreement was reached on names for the Istanbul professorships - and all were members of the Notgemeinschaft! However, it was clearly understood from the outset that the German professors were meant to stay only until their Turkish pupils could take over. Therefore, five-year contracts became the rule. Courses were to be taught as soon as possible in Turkish, using textbooks which had been translated into Turkish as well ${ }^{10}$.

On July 31, 1933, the Dar-ül Fünun was closed by government decree, as a means of canceling all existing good-for-life faculty contracts ${ }^{11}$. The very next day, Istanbul University was opened using Dar-ül Fünun's physical plant, a small fraction of the original faculty, and more than thirty world-renowned

6 Neumark 1980 noted that three revolutions came together to make the 1933 "miracle" happen in Turkey: Russian in 1905, Turkish in 1923, and Nazi in 1933.

7 Schwartz, organizer of the Notgemeinschaft, lost his sister and her entire family in Germany's gas chambers.

8 For details see Burk 2005, 235-257.

9 Müller 1998, 294-305.

10 Müller 1998,294-305.

11 On September 26, 1933, Shepard wrote to Lambert: "In order to have an effective reorganization however it was necessary to abolish the old University because according to law all the professors held office for life. With the abolition of the University the old Arabic name 'Dar-ülfünun' has also been abolished." (Emphasis added), Rockefeller Archives Center. 
émigré German professors who were on their way to Turkey. Incredibly, courses began on November 5, 1933, as reported in various media (fig. 1).

Most influential of all the physicians in Ottoman service were members of the Hamon (Amon) family. The [Hamon] family dynasty originated with Joseph Hamon born in Granada about 1450 who emigrated to Istanbul during the reign of Mehmed II and served as physician to Sultan Bayezid II and Selim $\mathrm{I}^{12}$.

According to Ottoman historian Stanford Shaw, the Hamon family was expelled from Spain during the Spanish Inquisition for being Jewish. Although the reader might have a picture of a quaint medieval hysteria, the Spanish Inquisition went on for three hundred years, lasting well into the 1800s.

By contemporary western standards circa 1930s, the Ottomans' medical legacy left much to be desired. Much of the medical "practice" was not based on recent science; some was not based on science at all. Infant mortality was known to be high and longevity short. However, epidemiologic "data" were rudimentary and mostly based on anecdotal information. There were questions on public health issues, to wit concern for local water quality standards. In the countryside, and much of Turkey was just that, all food distribution, preparation, and consumption, was "traditional". It may not have changed for hundreds of years, same for the "knowledge of dietary requirements".

In an agrarian society where meat was scarce or predominantly consumed by the upper class, protein was rare unless one lived on a seacoast. There were too few doctors

\section{L'Université ouvre le 5 Novembre}

Dans toutes les facultés de rUniversité. les cours commenceront le 5 novem bre prochain. Grâce aux mesures prises en temps utile, toutes les modifications et les réparations entreprises dans le bâtiment abritant l'Université, seront achevées d'ici là

La nouvelle Université turque entrera en aotivité dans des conditions tout à fait nouvelles.

La faculté des lettres a été complète ment transférée à l'hôtel Zeyneb Hanem. La Faculté de Droit est sur le point d'occuper les locaux de la Faculté des lettres. La construction du laboratoire destiné à la faculté de médecine dans l'édifice de Békir Agha Benlugu, sera achevée bientôt, de même que la modification des locaux transformés en laboratoires dans les hôpitaux de Djerrah Pacha, Hasséki et Gouréba et destinés à cette dernière faculté.

Fig. 1. Newspaper article from Le Journal d'Orient October 30, 1933.

\section{University Opens Fifth of November}

Courses will start on November 5 th in all faculties of the University thanks to all necessary measures being completed in timely fashion. All alterations and repairs in the building housing the University will be completed between now and then.

The new Turkish University will start its activities under completely new conditions.

The Faculty of Letters has been entirely transferred to the Zeynep Hanım Kona $\breve{g l}$. The Faculty of Law will soon occupy the locale of the Faculty of Letters. The construction of the laboratory in the Bekir A $\breve{g} a$ Binast intended for the use of the Faculty of Medicine will soon be completed. The same is true for alterations of spaces transformed into laboratories in the Hospitals of Cerrah Paşa, Haseki and Gureba for the same Faculty.

12 Shaw 1991. 
and too few clinics for the rural population. Those who attempted a practice in general did not have access to the latest technology as in radiology and surgery. It was obvious that Turkey desperately needed medical schools based on western medicine. She needed major infusions of western medical technology and know-how in its use. Her doctors needed to be brought up to date in medical methods.

It was with this as a scenario back in 1933 that Philipp Schwartz and the Turkish representatives in Basel began seeking candidates with impeccable credentials for the positions needed. All evidence shows that they did their job well and quickly. The medical contingent was by far the largest among the group. A survey of all academic Personnel Department files identified no fewer than seventy-six unduplicated "exile" names who worked in the Istanbul University Faculty of Medicine between the years of 1933 and $1950^{13}$. There were others at Ankara University's medical school, as well as at various government agencies ${ }^{14}$.

An excerpt from a February 3, 2005 article by Dr. Coskum Özdemir that appeared in Cumhuriyet, one of Turkey's largest-circulation daily newspapers:

My relations with İstanbul University are almost 59 years old. I entered the University of Istanbul as a medical student in 1946. That year, a law was decreed recognizing the autonomy of the universities. We were able to listen to interesting lectures given by world famous scientists gained as the result of the 1933 reform and German fascism. I always respectfully remember the pleasure and the love of science instilled in me by scientists such as Professor of pathology Schwartz, the colourful Professor of zoology, Kosswig, physiology Professor Winterstein, and internal diseases Professor Franklin.

Our [native] Turkish professors were also among the famous people of the country. However, why some of them were so hard and cruel vis-à-vis the students is a thing which has occupied my thoughts a lot.

Professor Özdemir is a prominent Turkish intellectual, who chairs the Turkish Association for Muscular Diseases, and is a staunch defender of Atatürk's reforms.

13 Namal 2005.

14 A Diary entry for Friday, February 16, 1934 by Dr. R. A. Lambert, who was sent to Turkey by the Rockefeller Foundation's European Office, states: "There is no doubt that the Turkish government is determined to make the Med. Fac. a first-class institution and that the authorities realize it will take more than five years to train Turks to succeed the German professors who have been brought in as heads of departments; it is expected that many of the five-year contracts will be renewed. The Turkish government, like that of [Soviet] Russia, is planning on a grand scale and wants quick results." Courtesy Rockefeller [Foundation] Archive Center. 


\section{Public health}

It may well have been a coincidence, but recognizing that Turkey had just come out of a series of wars which took place immediately on the heels of World War I, chances are that it was not a random happening: among the medical staff selected by the Schwartz organization were at least three who had established expertise in treating syphilis. These were Dr. Alfred Marchionini, who assessed its effects as a dermatological problem, Dr. Albert Eckstein, who considered its impact on children, and Dr. Joseph Igersheimer, who had already published a book on syphilis and the eye. The émigré team included several additional individuals concerned with public health. The most admired by the medical students of these was hygienist Julius Hirsch who became Professor of Hygiene ${ }^{15}$ and Director of the Hygiene In-

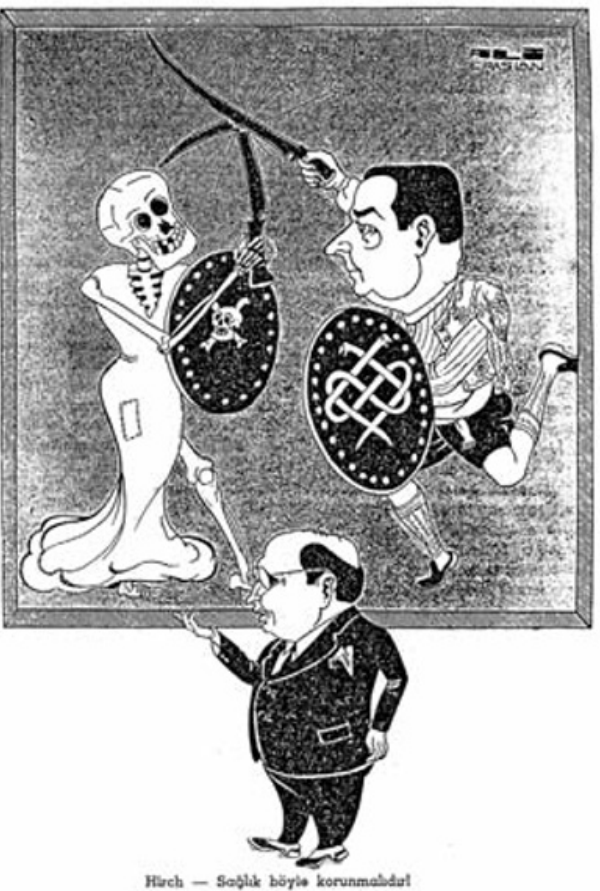

Fig. 2. "Saglik boyle korunmalidir." "Health should be protected like this." A cartoon of Julius Hirsch. Istanbul University's Medical School student New Year's spoof. stitute at Istanbul University after being released from the Kaiser-WilhelmInstitut für Biochemie and the University of Berlin in 1933 (fig. 2).

\section{Pathology}

The organizer of it all, Dr. Philipp Schwartz, was born in Werschetz, Hungary, in 1894. He was "the youngest Professor in all of Germany at the time" Schwartz was a major figure in the reorganization of Istanbul University along modern lines starting in 1933. The Turkish government sought his advice on hiring of more university teachers and government experts. At his suggestion, mathematician Richard Courant and Nobel laureate physicists James Frank and Max Born visited Turkey as scientific advisers ${ }^{17}$. In 1951, Schwartz returned to his post at Frankfurt University; in 1953, he moved to America where he served as a pathologist at the Warren State Hospital in

15 Public Health in today's parlance.

16 Shaw 1993, 359.

17 Fermi 1968, 67. 


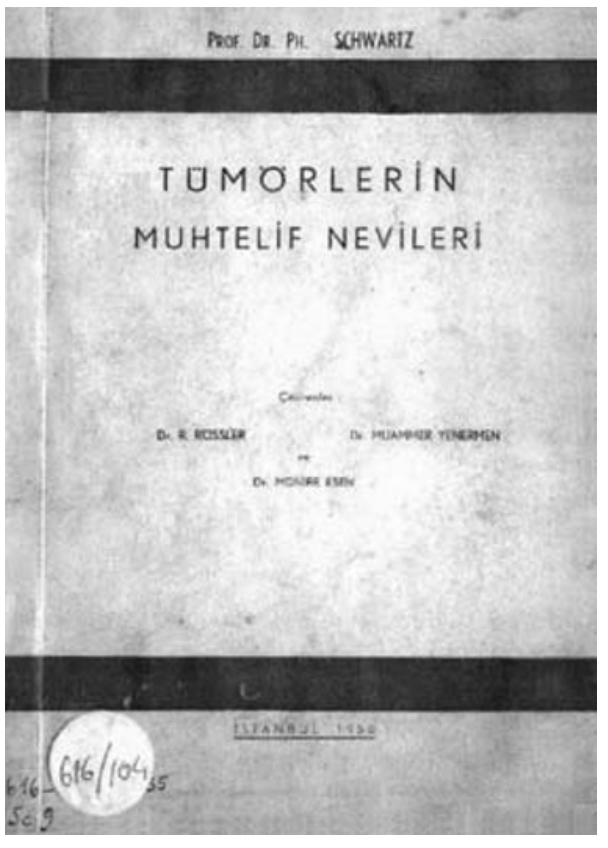

Fig. 3. Introduction to Tumor Science by Philipp Schwartz. 1950 edition.

Pennsylvania and continued his life-long research on cerebral birth lesions in the newborn.

Although Philipp Schwartz was not labeled a "social reformer", he played a most significant role in organizing emigration of a group of intellectuals who made possible important facets of Turkey's social reforms in all sectors.

Philipp Schwartz was not only trying to save lives, but also build a new institution. While still in Zurich, on behalf of the Notgemeinschaft in a letter dated October 6, 1933, he wrote to The Rockefeller Foundation's European office: "The Turkish Government is doing everything possible to facilitate our work. Our prestige in Turkey would, however, be greatly enhanced if we were in a position to say that the Rockefeller Foundation is assisting us." This set off a flurry of internal and external Foundation correspondence which culminated in financial support. Though the amounts were not great, the prestige was ${ }^{18}$. As indicated, in early 1934 the Foundation sent an emissary to Istanbul to survey the émigrés' integration and to report on their progress in reforming the university. The emissary was thorough; his diaries for February 17, 1934 state:

Schwartz is a confident, dynamic person - the kind of leader the situation requires. He strikes
me as being a little over-enthusiastic about the ability of the Turks. He says for example, that
the students are not only more serious than German students, but keener; they have not the
'blasé attitude of the Middle-European. Since very few of them know German and com-
munication must be largely through an interpreter, S' judgment may be premature. (S. is
rapidly acquiring Turkish; says his knowledge of Hungarian helps mightily.) But all lectures
must as yet be delivered through their Turkish assistants most of whom fortunately know
German.19 Time proved R. A. Lambert right.

Economist Fritz Neumark, "one of his oldest friends even during the Frankfurt days" 20 , remembers Schwartz in his memoirs as "the true "spiritus rector' of the whole Turkish venture" ${ }^{21}$.

18 Courtesy Rockefeller [Foundation] Archive Center.

19 Courtesy Rockefeller [Foundation] Archive Center.

20 Neumark 1982, 74

21 Neumark 1982, 74. 
With great sorrow, I have to say here that this extraordinary person was treated with distrust and even dislike by both Turks and Germans, something he generally did not deserve; he was not shown the appreciation he deserved for the great efforts he made for the refugees.

\section{As quoted in a 1953 biography ${ }^{22}$, Philipp Schwartz said:}

We have been able to remain loyal to the spirit which is the foundation of modern civilisation and humane feeling, and to impart that spirit, even in those dark days of history, to thousands of gifted young persons.

\section{Dermatology}

Alfred Marchionini of East Prussia served as Professor of Dermatology in Freiburg. He came to Ankara in March 1938 and stayed until February 1949. He was in Hamburg until October 1950 and later in Munich as Professor of Dermatology where he also served twice as Rector (President of the University). Dermatologist Richard Richter, who was later invited to Ankara, tells of Marchionini's work in Turkey in his "A Letter from Ankara" 23 as follows:

The department he took over was small and did not fit at all the description of a modern center of research in dermatology. However, the energy of Marchionini and his amiable cooperation with his colleagues in other departments made it possible to expand his clinic and establish an institute which could shoulder a large clinical workload. How Marchionini's influence was felt by a large section of the population is best evidenced by an increase of 24000 in patients applying to the clinic during one year; this, in a very conservative population which was cautious against innovation and even rejected everything new. To succeed thus in the most primitive clinical conditions deserves admiration. As if this would not suffice, advanced scientific research was being conducted, although they did not have their own laboratories and Marchionini opened new horizons in dermatological research with innumerable articles. His work on the climatophysiology and pathology of the skin, his initial descriptions of a disease's progression, new methods tried in the cure of sub-tropical diseases, will always provide a foundation and new dermatological research will continue to be conducted on this basis. His heritage continues to survive in the hard work of many of his students in Turkey today. ${ }^{24}$

Economist Neumark remembered Marchionini as "a typical Eastern Prussian", one famous as a dermatologist and as a specialist in venereal diseases. $\mathrm{He}$ "organised a German-French Week of interesting conferences and discussions in Munich, the aim of which was scientific sharing as well as rapprochement between German and French scientists" 25 .

22 Bentwich 1953, 55.

23 Richter 1954.

24 Widman 1988, 20.

25 Neumark 1980, 73. 


\title{
Gynecology
}

Wilhelm Liepmann was born in 1878, and, by 1933, he served as Director of the Cecilienhaus Women's Clinic and as Professor of Gynecology at the University of Berlin. He was at risk because his wife, Emma, was Jewish. So, in that fateful year, 1933, they moved on to Turkey where he served as Faculty of Medicine professor in Istanbul. Liepmann died in 1939. Fritz Neumark recalled that

\begin{abstract}
... besides Rudolf Nissen and ophthalmologist Joseph Igersheimer, gynecologist Wilhelm Liepmann especially became to be loved for his work as professor and clinic director in Istanbul. Liepmann, with his familiar but gentle manner not frequently seen among physicians, was known worldwide among his peers for his efforts while in Berlin to establish and develop the new branch of frauenkunde [gynecology]. He died in Istanbul after only four years of work. I met him there for the first time. With his quiet and friendly manner, he not only made numerous friends among his colleagues but also made good impressions on his patients. ${ }^{26}$
\end{abstract}

Willhelm Liepmann recognised the need for pregnant women to engage in prenatal physical exercise in the 1920s. This was quite a revolutionary point of view for the times. Significantly, the record shows that he maintained a personal correspondence with Albert Einstein.

\section{Internal medicine}

Alfred Erich Frank was the first to discover the class of anti-diabetic drugs that can be taken orally. He also made important discoveries in the area of thrombocytes. Dr. Frank's personal story is summarised by Professor Emeritus A. Kazancigil, a noted Turkish scientist, educator, and writer who owes his own education to the émigré professors. Frank

... came and settled here; he made his name here, grew old, and did not want to leave. These [German] people were very useful for Turkey in the long run. It is not that internal medicine was not existent in Turkey until then; it did exist. We had first-rate men but [Frank] started a whirlwind of change. Of course, there is also the matter of their deaths for those who stayed on. Many chose Turkish cemeteries. ${ }^{27}$

The state funeral given to Frank when he passed away in 1957 is an open indication of appreciation and love felt for him in Turkey. The Medical Faculty of Istanbul University ordered Dr. Frank's ${ }^{28}$ gravestone at Istanbul's Bebek

26 Neumark 1980, 70f.

27 Kazancigil 2000.

28 This section is based on a forthcoming paper by Arin Namal and Arnold Reisman, "A Tale of Three Medical Researchers Saved by Turkey from Nazism. They went on to impact healthcare delivery in Turkey, Israel, and the USA." 
STUDIES ON THE CONDITIONS OF GLUCOSE EXCRETION IN MAN

BY KURT STEINITZ

(From the Department of Medicine of Istanbul University, Guraba Hospital, Istanbul, Turkey)

(Received for publication September 29, 1939)

Fig. 4. Title and byline of a Steinitz paper written in Istanbul and published in America. Journal of Clinical Investigation, Vol. 19 (2) (1940) 299-305.

cemetery to be made and to be engraved: "Sleep in peace! Turkish medicine is grateful to you."

Kurt Steinitz ${ }^{29}$, a medical doctor and a Ph.D. medical chemist was born in Breslau, Lower Silesia, or Wroclaw, Poland, and obtained his medical degree from Leipzig in 1931. He left Germany immediately after Hitler came to power, since Jewish physicians were not allowed to work anymore in the non-Jewish hospitals. Steinitz first went to Italy where he did unpaid work in Milan. After a few months, he left for Palestine with a cousin on a tourist visa.

Notwithstanding his immigration status, Steinitz bought a farm in Ramoth Hashavim, a community north of Tel Aviv, where many German immigrants, mostly academics, opened chicken farms. He wanted to learn how to raise chickens and tend bees, there being no jobs for physicians in Palestine at that time. In 1934, he returned to Breslau, Germany, in order to marry Elisabeth Bruck.

Steinitz's, Breslau's mentor happened to be the famous internist Alfred Erich Frank who was among the original group of Notgemeinschaft invitees to Turkey. Frank was among those given the right to bring with him a competent assistant. Dr. Frank opted for two, each to be paid half of one salary. Kurt Steinitz was one, and Steinitz's sister-in-law, Dr. Erica Bruck, was the other. For reasons not stretching one's imagination, both accepted the invitations extended to them. In turn, they tried to bring Erica's mother, Ada Bruck, to Turkey but did not succeed. Ada Bruck was one of the six million who perished ${ }^{30}$.

While in Turkey, in addition to continuing his research activities with Drs. Frank and Bruck, Steinitz was active in setting up modern clinical testing laboratories. To facilitate work in the new clinics, he enabled the Internal Diseases Clinic's laboratory in Istanbul to perform most of the needed tests. Steinitz also published numerous articles (fig. 4). Their daughter, Irene, was

29 Ibid.

30 This section is based on an oral history provided by Elisabeth Steinitz, (Kurt Steinitz's widow), and recorded in Hod Hasharon, Israel, on August 10, 2005 by Miriam Schmidt. 


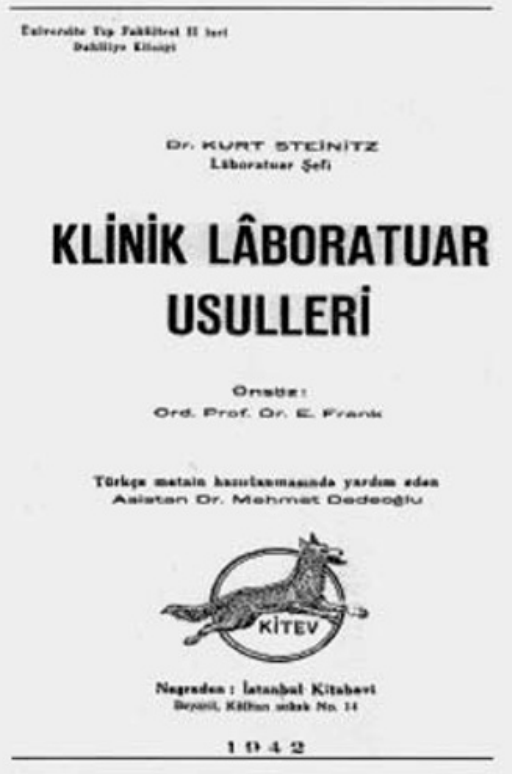

Fig. 5. Clinic Laboratory Procedures by Kurt Steinitz with a foreword by Alfred Erich Frank, 1942. born in Istanbul at the end of 1936. The family was forced to live a very frugal life on the husband's half-salary. During summer months, they lived in a very old Turkish house on the Asian shore of the Bosphorus and Steinitz moonlighted on one of the regular steamboat ferries crisscrossing the Straits. In winter, they lived in the old quarter of Istanbul.

The most significant service that Steinitz performed for Turkey was establishing the infrastructure for transferring conserved blood. This had never before been done anywhere in that part of the world. Not only was he successful in establishing the means to do so, he also published instructions for performing the procedures. Additionally, in 1942, he published the Turkish textbook Clinic Laboratory Procedures. His colleague, Dr. Alfred Erich Frank, wrote the book's preface, explaining its importance (fig. 5).

Steinitz's final contract expired on June 1,1943 and he went back to Palestine. There he first went straight to work for Kupat Holim, the national health service and insurance agency in the port city of Haifa and at the same time in a small inland farming community called Afula which is located in the Jezreel valley of northern Israel over 30 miles away. In the 1940s, a bus or train ride would have taken at least an hour (the train is long gone). To this day, with no more than 40000 residents "within Israel, Afula is known (somewhat rightfully so) as a boring, dusty place in which it is far from desirable to live, whose inhabitants are close-minded, and all dress and act the same" ${ }^{31}$.

Between 1945 and 1960, Steinitz was on the staff of the Rambam, the major research and teaching government hospital in Haifa. At the same time, he worked for Haifa's Roschild Municipal Hospital. Between 1960 and 1966, he directed the chemistry laboratories of Beilinson Hospital in Petah Tikva, a prominent research institution. Steinitz died in 1966.

Kurt Steinitz built the first artificial kidney in Israel and continued to publish in the best-refereed journals worldwide. Many of his publications are still available through the services of Pub Med. Unfortunately, Steinitz was never given a university appointment in Israel. 


\section{Pediatrics}

Erica Bruck ${ }^{32}$, a pediatrician whose life was saved by Turkey in 1934, left Istanbul for the United States in 1939 for a number of reasons. One of these was to make it possible for the growing Steinitz family to have the full Assistant's stipend - she had been living on half. In America, Dr. Bruck enjoyed a brilliant medical career, serving as a pediatrician at the Children's Hospital of Buffalo for fifty years. She published many seminal research articles, such as the "Renal Functions in the Course of the Nephrotic Syndrome in Children" published in the Journal of Clinical Investigations in 1954. Another was the paper on the "Perfusion of the Underventilated Compartment of the Lungs in Asthmatic Children", published in the same journal in 1964. During the course of her life in Buffalo New York, she was very active in many causes affecting children worldwide, including the initiative to ban land mines and constant work to assure equitable housing opportunities as in the membership-based nationally recognized civil rights organization called HOME. Her life was saved in 1934 by Professor Frank's ability to invite her out of a Nazi hell and Kurt Steinitz's willingness to share the one-person Assistantship billet at Istanbul University.

It is difficult to contemplate the number of lives Erica Bruck affected while serving as pediatrician at Buffalo's Children's Hospital for fifty years. It is also mind-boggling to consider her impact on the health of children everywhere and forever as the result of her published research, most of which was based on clinical studies. And if that were not enough, as a member of the National [US] Committee for Clinical Laboratory Standards, Erica Bruck co-authored at least six procedure manuals on collection of blood for diagnostic purposes, which continue to set the standards for today's medicine ${ }^{33}$.

It is interesting to note that Howard Faden, M.D., and Linda Duffy, Ph. D., from the Department of Pediatrics, State University of New York, School of Medicine and Biomedical Sciences and Margot Boeve, from the Ryksuniversiteit Groningen, Groningen, of the Netherlands conclude their 1998

32 This section is based on a forthcoming paper by A. Namal and A. Reisman, "A Tale of Three Medical Researchers Saved by Turkey from Nazism. They went on to impact healthcare delivery in Turkey, Israel, and the USA."

33 These are: (1) Devices for collection of skin puncture blood specimens - second edition (approved guideline). (2) Evacuated tubes for blood specimen collection - third edition (approved standard). (3) Percutaneous collection of arterial blood for laboratory analysis second edition (approved standard). (4) Procedures for the collection of diagnostic blood specimens by skin puncture - third edition (approved standard). (5) Procedures for the collection of diagnostic blood specimens by venipuncture - third edition (approved standard). (6) Procedures for the handling and transport of diagnostic specimens and etiologic agents - third edition. 
article "Otitis media: back to basics" which appeared in the Pediatric Infectious Disease Journal ${ }^{34}$ with: "We dedicate this article to Dr. Erica Bruck on her ninetieth birthday. Dr. Bruck served as a pediatrician at the Children's Hospital of Buffalo for 50 years."

When contacted about the dedication, Howard Faden, M.D., stated, "She was among the most astute faculty we had. A great physician and I use the term 'great' rarely. When others could not figure out the diagnosis, they invariably turned to Erica." 35

By far the most interesting of all the émigré "healers" in Turkey was pediatrician Albert Eckstein. As often is the case, Dr. Erna Schlossmann-Eckstein, also a pediatrician, and the daughter of Weimar Germany's renowned pediatrician Arthur Schlossmann, often operated in the shadows of her husband. Often, but not always! Dr. Erna Schlossmann-Eckstein did accompany her husband and his Turkish assistant on many forays into Turkey's hinterland villages to collect some of the country's first public heath statistics. She was an acknowledged member of the team on these data-collection expeditions.

Albert Eckstein was indeed a social reformer in the field he knew best pediatrics. He "made major contributions to the treatment of children's illnesses by creating a series of clinics throughout Turkey" ${ }^{\prime 3}$. He also redesigned the country's pediatrics curricula. Ordinarius Professor, Albert Eckstein was the architect of modern pediatrics in Turkey. His contributions to Turkey and to helping save other Jewish refugees from the Nazis were so multifaceted and each so significant that they will receive a disproportionate amount of space in this article. This man brought with him the latest knowledge and the latest technology in pediatrics health care delivery to a society in desperate need for such. But he did even more. He used his personal rapport with ministers of state to enable the right of passage through Turkey, for groups of Jews fleeing the Nazis and heading for British-controlled Palestine. Eckstein was remembered and honoured in 2005, the sixtieth anniversary of his founding the Pediatric Clinic at Ankara University.

The issue displayed here (fig. 6) reports on Eckstein's contribution to the treatment of noma, a childhood disease eradicated in Turkey thanks to Albert Eckstein.

Noma (cancrum oris) ${ }^{37}$, a devastating, gangrenous disease found almost exclusively in young malnourished children, was eradicated in Turkey by

34 Volume 17 (12) December 1998, 1105-1113.

35 Personal communication, September 12, 2005.

36 Shaw 1991.

37 This section is based on Akar and Can 2005. 


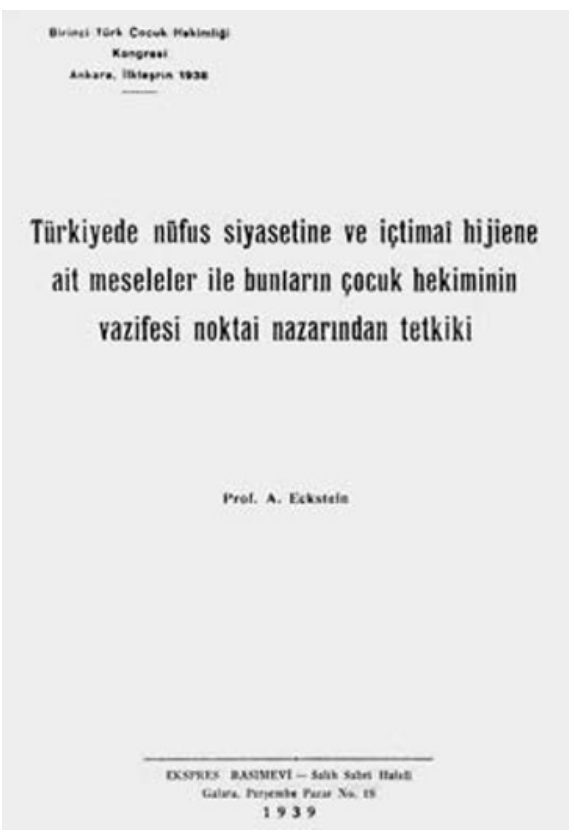

Fig. 6. 1947 Turkish medical journal cover.
Dr. Albert Eckstein ${ }^{38}$. He was the first to introduce modern public health concepts and methods to that impoverished land. Eckstein was born on February 9, 1891 in Ulm, Germany. He studied medicine in Freiburg. In World War I, he was awarded the "Eisernes Kreuz First Class", the German Honor Cross, First Class, for heroism ${ }^{39}$. Following the war, he worked at the Physiology Institute, University of Freiburg. In 1920, he moved to the University Hospital for Children to work under Carl T. Noeggerath, a very famous pediatrician at the time. In 1923, he became a senior lecturer based on his work, "Influence of natural and artificial light sources on the growth of young rats with simultaneous variation of their living conditions" ${ }^{40}$.

Eckstein married Erna Schlossmann, a pediatrician whose father, Arthur Schlossmann, was head of the Children's Hospital at the Academy of Medicine in Düsseldorf. In 1926, Eckstein was promoted to the rank of professor. After Arthur Schlossmann's death, Albert Eckstein was appointed chief of the department and had reason to look forward to a brilliant career in the land of his birth ${ }^{41}$. However, on July 1, 1935 in his Düsseldorf clinic, Dr. Eckstein received an envelope marked "Personal". It read: "In the name of the Reich, I relieve you of your duties in the service of the Prussian Government by June 1935 based on the orders dated 12 June 1935. Adolph Hitler, Hermann Göring." ${ }^{42}$

\section{Ear, nose and throat}

Professor Dr. Karl Hellmann was born in Würzburg, Bavaria, on September 8, 1892 and died in 1959. He was among the small group of health professional who went from Turkey to Palestine. Two of his daughters, Erica and Miriam went to Palestine with him, and the third, Frances (Franciska),

38 Akar 2003.

39 Akar 2003.

40 Akar 2003.

41 Akar 2004; Ash and Sollner 1996.

42 Moll 1995, 1204-1207. 
married archaeologist, philologist, and historian Hans Güterbock who obtained a prestigious position at the University of Chicago. Hellmann received most of his higher education in his home town, Abitur (1911) in Würzburg, up to and including his Doctor of Medicine in 1920. Between 1912 and 1919, he served in the German army. From 1924 to 1928, Dr. Hellmann was employed in Westphalia's Münster University as an ear specialist. In 1928, he became the clinic's acting director. From 1930 to 1935, he was back at the University of Würzburg as professor and head-physician at its Ear, Nose, and Throat (ENT) Clinic (fig. 7). Dismissed in 1935, Professor Hellmann sent his biography and list of publications to the Rector of Istanbul University from Würzburg. He came to Istanbul in 1936 via the Orient Express with his wife and three daughters. Hellmann replaced another German, Professor Ruttin, as Director of Istanbul University's ENT Clinic. Ruttin could not get the support he requested for modernizing the clinic, so when he left Turkey for Austria, Hellmann managed to have the clinic moved to a building in much better condition, increased the number of patients examined, and devised a technique that enabled laryngectomies to be performed in a much shorter period of time. He was able to bring his relatives (including a brother Bruno who was already in the Buchenwald ${ }^{43}$ concentration camp) from Europe to Turkey in 1939. Because his contract was not renewed, Hellmann left Turkey for Palestine at the end of summer $1943^{44}$.

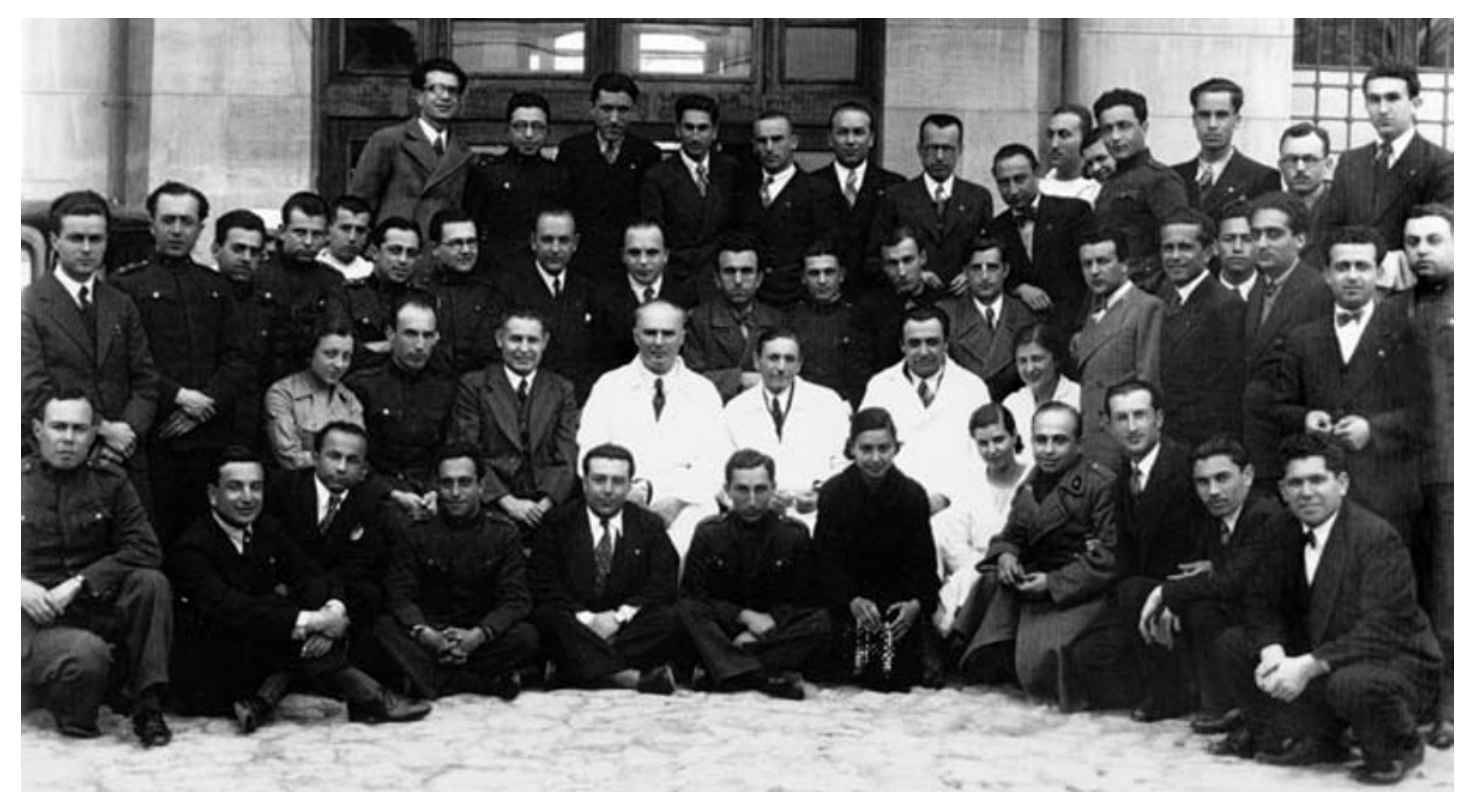

Fig. 7. Dr. Hellmann and his former ENT residents. Some are wearing military uniforms.

43 Personal communication with Miriam (Hellmann) Schmidt. April 5, 2006. 44 Namal 2005. 


\section{Ophthalmology}

"Over 2000 American ophthalmologists had listened to his lectures."

And Joseph Igersheimer did not start lecturing American doctors before his sixtieth birthday. Igersheimer was a Jewish German-born ophthalmologist. He had chosen his career in ophthalmology because, as a teenager in the early 1900s, he had contracted tuberculosis. While recuperating at a Swiss sanatorium, he noticed that many fellow tuberculosis patients had an unusual marking, a white area in their eyes. He began examining their eyes and this led to a lifetime fascination with how other diseases affect the eyes $^{46}$.

Igersheimer completed his medical education in Heidelberg, Berlin, Strasbourg and Tübingen,

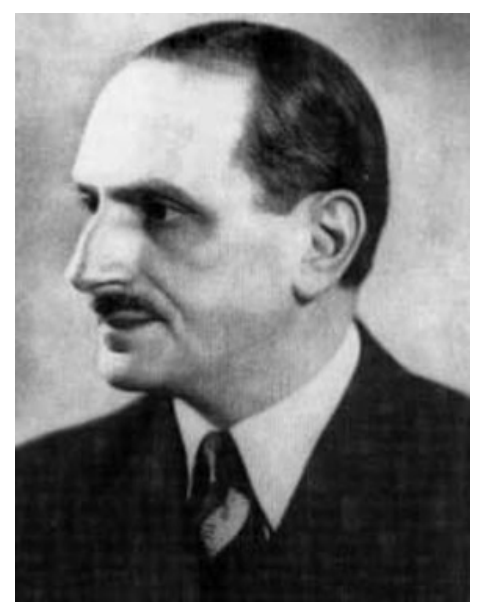

Fig. 8. Joseph Igersheimer ${ }^{1}$. 1 This section is based on Namal/Reisman 2005. and received his degree in 1904. Between 1905 and 1909, he worked his way up from assistant to an Assistant Professor in Heidelberg. He became full Professor in 1914 and "Extraordinary Professor" in 1925. He was the "Head Physician" in Göttingen between 1915 and 1925, before his appointment at the University of Frankfurt.

Starting in 1915, he was first in the world to use arsphenamine for the treatment of syphilis of the eye. He was among the first to write articles and books addressing the impact of syphilis on eyesight. In 1919, the Springer Verlag in Berlin published his seminal text, Syphilis und Auge (Syphilis and the Eye). Igersheimer was the first to operate for retinal detachment by closing off the holes. He did all this before 1926, at which time he became full professor in Frankfurt-am-Main. It looked like he had a brilliant future in Germany's highly advanced medicine. Then came January 30,1933.

Igersheimer was Jewish as was his wife, Alice. Realizing that the worst was yet to come, Igersheimer, like many others, looked for ways of leaving his beloved heimat. He was looking for a place that would not only offer refuge but an opportunity to practice his love of ophthalmology. He did not have the option of going to a job waiting for him. Like his compatriots, he was keenly aware of the lack of university job opportunities due to widespread discrimination and the worldwide Great Depression. Fortunately for Igersheimer, Schwartz's Notgemeinschaft came through.

46 Igersheimer's son, Walter, personal communication, August 21, 2005. 
Igersheimer was in the first party of scientists to arrive in Turkey. On October 15, 1933, he took charge of Istanbul University's Institute of Ophthalmology, a section of its Faculty of Medicine. Igersheimer's first contract with the Turkish government covered the period November 15, 1933 to November 15, 1938. During the second week on the job, Igersheimer delivered his first Istanbul lecture, in German, on "Blindness and Its Causes".

The past is prologue. In his new and very foreign environment, while building his practice from a zero base, constructing a modern eye clinic, training medical residents despite a language barrier, writing papers and books in German, giving seminars to dental students and faculty on the relationship between tooth and eye diseases, and introducing cases he found interesting at meetings of the Turkish Medical and the Turkish Ophthalmology Associations, Igersheimer was expected to speak Turkish by 1936, three years after arriving.

\section{Surgery}

Wars are designed and managed for to kill and maim. Those killed are statistics, at best, memories. For the maimed survivors, civilized society is obligated to provide care through the healing process. Among the healers, surgeons are in great demand. Turkey had quite a great need in the aftermath of the many years of its wars, but it did not have enough qualified surgeons to meet it. Many surgeons had to be trained.

One of the invited teaching surgeons was Dr. Rudolf Nissen who did pioneering work in thoracic surgery, and the treatment of gastro-oesophageal reflux disease (acid reflux) and hiatal hernia. He performed the first successful pneumonectomy (surgical removal of entire lung) in humans. The Nissen-Rossetti type of fundoplication (procedure that alleviates chronic heartburn in people whose condition cannot be controlled by either lifestyle changes or medication) has remained the standard procedure in Europe and the USA ${ }^{47}$. Nissen developed these procedures while still in Germany and imported them to Turkey and later to the US.

The first modern anaesthesia machine had been brought to Istanbul Medical School by Prof. Rudolf Nissen ${ }^{48}$. Nissen had trained as a voluntary physician and assistant in pathology at the universities of Breisgau and Freiburg and had planned to take over his father's clinic in Neisse. However, in September 1922, he received a surprising invitation to work with Ernst

47 Liebermann-Meffert/Rossetti 1996.

48 Reisman 2006, 164. 
Ferdinand Sauerbruch (1875-1951) in Munich. This was the beginning of many fruitful years of work. In 1926, he brilliantly defended his doctoral dissertation. The next year, he followed Sauerbruch to the Berlin Charité, where he became Sauerbruch's deputy and Professor Extraordinary in 1930.

When the Nazis came to power, he saw that Germany was not the place to stay. On May 29, 1933, Nissen married Ruth Lieselott and together they left Germany for the United States of America. However, at their stop in Zürich, Nissen received a telegram from the Turkish government with a request that he assume the Chair of Surgery at the University of Istanbul. Nissen enjoyed life on the Bosphorus. He organized a clinic based on the Sauerbruch model for his scientific work. He also had the opportunity to go on study journeys, visiting the US and the Soviet Union, and took lively part in several professional conventions in Europe. However, the close friendship and commercial relations between Turkey and Germany in the years preceding the onset of the war in Europe in the late 1930s gave the émigrés and Nissen cause for concern.

When his contract expired in 1938, Nissen emigrated to the United States of America with his family, settling in New York where he opened an ambulatory surgical practice. He had to come to the United States in 1939 for treatment of a lung abscess due to a retained bullet from World War I. Additionally, he had the opportunity to perform major operations at the Brooklyn Jewish Hospital, and obtained a position as Associate Professor at the Long Island College of Medicine.

In 1948, he visited Germany and met his old friend and mentor, Sauerbruch, for the last time. In 1951, he accepted the offer of a Professorship in Basel and entered office in 1952. In his inaugural address, he took the opportunity to speak his mind about the Nazis. He remained in this tenure until 1967. In 1966, Rudolf Nissen was made a Doctor of Honour of the Humboldt-Universität zu Berlin. He was presented an honorary professorship from Hacettepe University, Ankara in 1973. Nissen was a critical observant clinician, an efficient and popular physician, and a teacher.

He worked with discipline and in cooperation with his Turkish colleagues, such as Ahmed Burhaneddin Toker, Fahri Arel, Dervis Manizade, and others who went on to become the leading authorities of general thoracic (chest cavity) surgery in Turkey. During his six years of residence and working in Istanbul, he contributed highly to the practice of general and thoracic surgery. Nissen stayed in New York and later in Basel until his death on January 22, $1981^{49}$.

49 http://ats.ctsnetjournals.org/cgi/content/abstract/69/2/651. Viewed September 25, 2005. 
Nissen left a deep and indelible impression on everybody he met. Similar to all extraordinary people who had exceptional expectations both from himself and his colleagues, he was both much loved and much feared. An indication of how he was loved by the Anatolian people is the name of "Nissen" given to their children by many village women successfully treated by $\operatorname{him} .^{50}$

Eduard Melchior, born 1883, was dismissed from his position as professor in Breslau and head of the Division of Surgery at the Wenzel-Hancke-Krankenhaus in 1935 because of his Jewish ancestry. He stayed and worked in Turkey until 1954. During those decades, he trained several generations of Turkish surgeons. An acclaimed surgeon, he became Professor of Surgery at the Nümune Hastanesi hospital in 1936, and from 1946 until 1954 he was a member of the Medical Faculty in Ankara. He retired in 1954 and returned to Germany, settling in Jugenheim. In 1966, he moved to Switzerland. Eduard Melchior died in 1974.

\section{Dentistry}

As ophthalmologist Igersheimer had been, Alfred Kantorowicz was also called upon to help Iran's Shah during his visit in 1934. The Shah Reza Pahlavi had come to observe first-hand Atatürk's reforms with the idea of introducing their equivalents in his own country (fig. 9).

While the two rulers sat for lunch talking politics, the Shah suddenly commented on the wonderful teeth of the Gazi (affectionate for Atatürk), whereupon the Gazi took them out of his mouth. Full of admiration, the Shah exclaimed that he also wanted such teeth. The Gazi obligingly said that he had a remarkable professor of dentistry who would make him a set of teeth outshining all others.

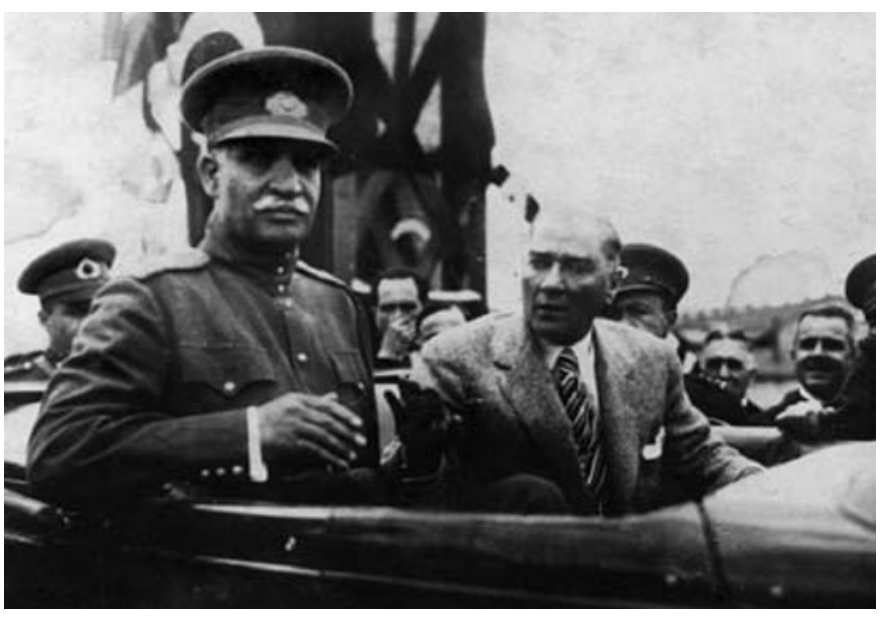

50 Neumark1982, 52-76.
Fig. 9. Shah Reza Pahlavi on his official visit to Turkey in 1934. 
Therefore that night, past midnight, Army trucks with torches (flashlights) suddenly drove up to the house of our dentistry professor and friend, Professor Kantorowicz who lived near us. The soldiers loaded him and his paraphernalia on the truck, drove to his institute, tore the dentistry chair from its concrete moorings, and deposited the whole kit and caboodle in the Palace of Dolmahbahce ... as the Shah could not be treated at the dental school for fear of an assassination attempt. ${ }^{51}$

The Shah left Istanbul very pleased with the new dentures Kantorowicz had made for him. However, earlier, this very same Kantorowicz had a close call with certain death. To wit, in a letter from Zürich, marked CONFIDENTIAL and dated October 6, 1933 to Professor Lauder W. Jones at The Rockefeller Foundation's European office, Professor Philipp Schwartz wrote on behalf of the Notgemeinschaft:

May I further take the liberty in this purely personal letter of submitting to you another delicate matter.

Colleague Kantorowicz: Bonn, who was appointed professor of dentistry and whose contract had already been signed by the Turkish government is being held in a concentration camp. I hope the Turkish government, in so far as it is able to, will assist us in freeing this worthy colleague. Might it not be possible that you also could use your efforts in behalf of Mr. Kantorowicz and induce the authorities in Germany in a friendly manner to free $\mathrm{Mr}$. Kantorowicz? This idea is, of course, only a suggestion. I do not know whether it is possible for you to exert such an influence. ${ }^{52}$

Pediatric dentistry innovator, Kantorowicz was born in 1880 . He received his dental degree in 1900 and his medical degree in 1906. He was Director of the Dental Institute in Bonn, Germany, in which capacity he served for fifteen years. He was an amazing leader with a special interest in pediatric dentistry. He developed preventive dentistry programs and mobile clinics for children in Germany. "His work in making the benefits of dentistry available even to the poorest sections of the population" was highly regarded throughout the dental profession in pre-Nazi Europe.

In 1933, the Nazis took Kantorowicz into "Protective Custody" and kept him for four months at the prison in Bonn. He was transferred to the Gestapo-, SA- (Storm Troopers), and SS- (Protective Squad, Schutzstaffel) run Börgermoor hard-labour concentration camp for four months, then was transferred to Lichtenburg, the concentration camp for prominent socialists, Jews, and intellectuals.

51 Von Hippel, A. (76) http://vonhippel.mrs.org/vonhippel/life/AvHMemoirs9.pdf. Viewed October 7, 2005.

52 Courtesy Rockefeller [Foundation] Archives Center. Kantorowicz was first a prisoner of the Nazis at Börgermoor: Langhoff 1935, 184-186. Additional evidence shows that the Rockefeller Foundation claimed to be unable to interfere directly in the matter of extraditing Kantorowicz from the concentration camp. 
According to a letter ${ }^{53}$ signed by philosopher Hans Reichenbach, who had already relocated to UCLA from Istanbul, and theoretical chemist Fritz London, who was at Duke University, Kantorowicz was released because of pressure from prominent authorities in Scandinavian countries, after which he came to Turkey. However, with due respect to Professor Reichenbach, because Alfred Kantorowicz was already sought after by the Turkish government - a contract had already been signed - there is reason to believe that it was the Turkish connection that played the more significant role in the Kantorowicz release from Lichtenburg and safe passage to Istanbul.

Kantorowicz worked in Turkey from 1933 until his retirement in 1948. During this period, he was instrumental in modernizing Turkey's dental curricula ${ }^{54}$.

When he arrived in Turkey, dental education was a three-year [post-high school] program and the clinical areas were divided into prosthodontics and conservative dentistry and were based primarily on the French educational system. He separated surgery from general dentistry, obtained the transfer of aesthetic surgery of the face (including cleft lip and palate) into the dental curriculum from the medical department, and introduced orthodontics into the curriculum. The curriculum was also lengthened to four years. He published several textbooks for dentists and auxiliary personnel. In 1943, he published a text on modern dental surgery (Distababeti Sir Rjisi) translated by Pertev Ata ${ }^{55}$.

Kantorowicz was among the outstanding professors and held many patents for his research ${ }^{56}$. As director of dentistry, he tried to create a department similar to its American counterparts. Not only was he one of the best and brightest scientists to live and work in Turkey, Kantorowicz was also a dedicated social reformer for most of his adult life. Between 1936 and 1938, he fought in Spain against Franco, the first major stand against the Nazi ideology and a testing ground for the rebirth of Germany's armaments industry. He had many articles as well as books on political and social matters published in the USSR and in the West.

53 The carbon copy of this letter does not show the date of the letter which was addressed to the Emergency Rescue Committee in New York City requesting a "non-quota immigration visa for Professor Alfred Kantorowicz ... Director of the Dental College at the University of Istanbul". In greatest likelihood, it was sent early in 1940 because of the return address used by Reichenbach. Courtesy The Grenander Department of Special Collections \& Archives, University at Albany, New York.

$54 \mathrm{http}: / /$ www.ncbi.nlm.nih.gov/entrez/query.fcgi? $\mathrm{cmd}=$ Retrieve $\& \mathrm{db}=$ PubMed\&list_uids=825 $8568 \&$ dopt $=$ Abstract.

55 Loevy and Kowitz 1993, 263-269.

56 http://litten.de/fulltext/kantoro.htm, http://www.istanbul.edu.tr/dishekimligi/. Viewed October $25,2005$. 
In 1950, Kantorowicz returned to Germany from Turkey and continued his work on dental research and caries prevention. His "Lectio Aurea" took place on February 17,1962 in the auditorium of the new and as yet unnamed dental institute of the University of Bonn. He was awarded many honorary degrees (Honoris causa) including one in medicine in June $1955^{57}$. As a great sportsman, Fritz Neumark recollects that

Kantorowicz was one of the first to "discover" Uluda $\breve{g}$ in Anatolia as a very suitable place for skiing which was almost unknown in Turkey then. My wife and Rosemarie Heyd-Burkhart were among the pioneers who had the courage to go up this mountain in the winter of 193435 under very primitive and exhaustive conditions. ${ }^{58}$

If one were to ask what the most significant and lasting impact on Turkey's health status made by the émigré "healers" as a group was, the answer would surely be that Turkey learned how to practice methods of public health years, if not decades, ahead of when most of the world recognized the need and benefit of the same. And, most, if not all, of these healers were social reformers with political agendas of their own to fulfil.

Thus, well over four centuries after an expellee from Spain became the personal physician to the Ottoman court, expellees from Nazism were invited to serve in the establishment of western medical standards within the Turkish Republic.

\section{Turkey's educational status, the need for reform and Igersheimer}

The Turkish university's library did not have a good collection of books on modern ophthalmology nor did the clinic have the requisite tools for Igersheimer to perform his work properly. For those, and for personal reasons (money), he wanted to bring his books and various clinic tools to Turkey. He had left them behind because the cost of approximately 7000 Reichsmarks in Turkish customs duties was excessive for him at the time. However, the Turks had promised that no customs duty would be applied if the medical goods came within three months of his arrival. Because of the delay of the shipments' arrival, Igersheimer ended up paying the customs and donating his medical books and tools to the University on condition "that they be used by the students".

On March 3, 1934, Igersheimer wrote to the Dean of the Faculty of Medicine:

57 Loevy and Kowitz 1993, 268.

58 Neumark 1982, 70. 
I do not have much information regarding the education of our students prior to the university. $40-50 \%$ of my students could understand and talk a little bit of French as far as I can figure out. Only 3 students out of 60 know a little German. On the other hand, Latin is a language that Turkish students do not know at all and hence that situation makes understanding of medical terms very difficult for them..$^{59}$

In a letter to the Faculty of Medicine Dean's office, he made his position quite clear: "Current equipment of Istanbul University Eye Clinic is not adequate." In the same letter, he pleaded that the government extend a contract to his assistant Susanne Hofmann who had worked for him at the University of Frankfurt and who had come to Turkey in order to work with $\operatorname{him}^{60}$.

A notice in a monthly medical journal, circa 1934, states: "The operation performed on the eye of Ex-Minister of Finance Abdülhalik Bey by Ophthalmology Professor Igersheimer was similar and even more difficult and important than the operation on the other eye performed in Vienna. This operation met with success." ${ }^{61}$ On December 10,1935, Igersheimer was asked to go to Ankara. The purpose of that trip was to examine and treat Tevfik Aras, Minister of Foreign Affairs.

Reflecting on his years in Turkey, another exile, Prof. Dr. Rudolf Nissen, comments about Igersheimer in his book Erinnerungen eines Chirurgen: "To watch this respected, intelligent, impressive person at work was always a pleasure. He was first to establish a personal relationship with the government by operating on the President of Parliament." 62

Another émigré colleague, economics professor Fritz Neumark, commented in his memoir about how he personally benefited from the developments that Igersheimer had ensured:

I owe much to Igersheimer. My son developed a sudden cornea difficulty when the Second World War had just started and Igersheimer was already in Boston. His young Turkish colleague, Prof. Dr. Naci Bengisu, who replaced Igersheimer, examined my son and said that he needed immediate surgery and performed it in a timely manner. This operation was pioneered by a Dutch doctor in the beginning of the 1930s and it was very difficult under the best of circumstances. Igersheimer taught the method to his Turkish colleagues. Thus, he indirectly saved my son from being blind. ${ }^{63}$

59 Courtesy University of Istanbul Archives, personnel records.

60 Hoffmann, being Jewish, was thus saved from the Nazis. She came as a single woman but left Turkey married to émigré physiology professor Hans Winterstein. In 1956, they returned to West Germany. In a two-page letter handwritten in French to the Istanbul University rector Igersheimer pleads reconsideration of the university's decision not to renew his former assistant's (Miss Susanne Hoffmann) contract. The letter was dated May 29, 1940 and written in Boston. As a good measure via a telegram, he announced to the rector that the letter had been sent.

61 Anonymous 1934, 2412.

62 Nissen 1969, 212.

63 Neumark 1982, 102f. 
According to Neumark ${ }^{64}$, on a visit to Turkey, the Shah Pahlevi of Iran complained to Atatürk about an eye problem, whereupon Atatürk recommended one of "his" German specialists. After a thorough examination Igersheimer pointed out that all the Shah needed was a new pair of lenses and proceeded to write their prescription. When Igersheimer returned to the front office after the examination, he found the Shah's aide-de-camp who asked that Igersheimer choose the frames. Igersheimer answered that his majesty can choose a frame with the assistance of any optometrist. The aide got down on his knees and pleaded that Igersheimer make the selection as he had forgotten to mention this to Igersheimer at the outset of the examination process and that this was an order from his master. If Igersheimer did not comply with that command - he would have immediately been booted out of his aidede-camp position.

At this point, Neumark offers an explanation. "The Shah came from humble circles. Politically astute he went from the rank of sergeant in Iran's army to become the country's head of state. As can be gathered, the Shah still preferred ancient Oriental traditional ways. Igersheimer selected the frames."

Igersheimer's students were well aware of his fame. In their 1935 yearbook, they entered his caricature and affectionate comments ${ }^{65}$.

Despite inadequate clinical conditions, Igersheimer performed the first "keratoplasty" procedure in Turkey. This fact was discussed by Prof. Dr. Naci Bengisu: "Keratoplasty was applied for the first time by Igersheimer via the v. Hippe ${ }^{66}$ trepan in the form of autokeraplasty in the University Eye Clinic in the last months of the year 1935." ${ }^{67}$ Since the blindness phenomenon due to loss of transparency of the cornea ${ }^{68}$ was often encountered in Turkey, keratoplasty was a frequently required operation in the country. However, only a total of thirty-four keratoplasties were performed in Turkey between the years of 1935 and 1939. Bengisu explained the reasons of not being able to perform many keratoplasties as follows:

64 Neumark 1982,70f.

65 See Tip Yolunda Yılbaşı Dergisi 1935, 16.

66 Eugen von Hippel (1867-1939) was professor of ophthalmology in Königsberg and a pioneer in the field of corneal grafting. His nephew, Arthur von Hippel, was one of the émigré professors in Turkey. He re-emigrated to the USA, joined the MIT faculty, and is considered the Father of Nanotechnology.

67 Igersheimer 1988, 68f.

68 Since trachoma was very common in countries east of Turkey, Turkey was also seriously affected by the problem. In 1923 after its founding, the Republic of Turkey started to fight this illness. A trachoma hospital was established in the eastern Anatolian city of Malatya where trachoma was most prevalent. See Fight against Trachoma Association President Dr. Nuri Fehmi's radio conference text. İstanbul Seririyatı 1935 (XVII) 3:15-17.1281 (28.4\%) of the 4508 blindness cases diagnosed in 110,995 patients that had been referred to the University Eye Clinic between the years of 1934 and 1943 were due to cornea thicknesses. 
There were many reasons for this sparseness. In the beginning, it was necessary to deal with the patients. Patients that had been accepted to the clinic were backing down from the operation and were leaving the clinic when they had learned that a piece from a dead eye would be taken. We contended with the corpse washer of our hospital for a while. He was not informing us when there were fresh cadavers. Another obstacle was the freshness of the cadavers. Generally, we were not able to extract from the patients that had been just passed away. We had to extract from the cadavers that had passed away five-six hours ago. ${ }^{69}$

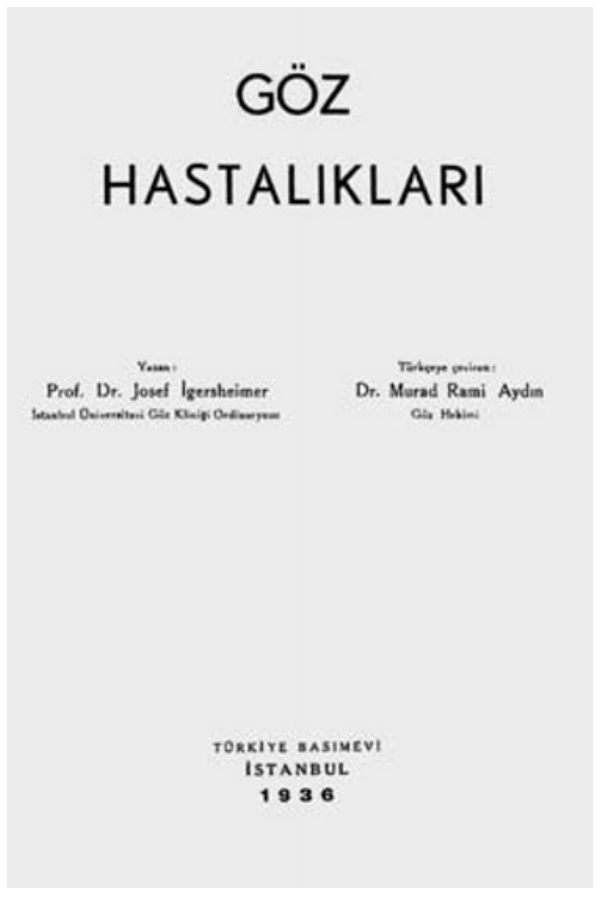

Fig. 10. Front cover of Igersheimer's Turkish textbook Eye Diseases, with Dr. Murad Rami Aydin as translator.

By contract, Igersheimer was obliged to write a Turkish textbook in his field within three years of arrival. With time to spare, in March of 1936, he published the 228-page textbook, Eye Diseases, which was translated by Dr. Murad Rami Aydin into Turkish (fig.10). In the book's preface, Igersheimer noted that the textbook had been designed as a guide to diagnosis and treatment for students and general practitioners. However, he emphasized that no such textbook should ever replace didactic instruction and clinical patient demonstrations. The book discussed most of the prevalent eye problems in Turkey such as "trachoma". A substantial number of the book's pictures were drawn by Jewish émigré Kläre Krause, the Faculty's illustrator. The second edition of the book was published in 1942, long after Igersheimer had left for the United States.

According to Igersheimer's Turkish colleagues, his unique studies and instructive articles took their place in important medical journals of the country. His studies of syphilis revealed the relevance of uveal (of or relating to the uvea of the eye) inflammation, and his dealing with secondary syphilitic side effects while in Turkey have engraved Igersheimer's name in the world's medical literature. On the other hand, documents in the Istanbul University Personnel Department Archives show that during May of 1939, Igersheimer wanted to go to a Turkish region having a high incidence of trachoma in the southeast (near Palestine), however, his request for permission was, for rea-

69 Igersheimer 1988. 
sons unexplained, actually turned down ${ }^{70}$. This happened to have been a surprising departure from Turkey's "unfailingly polite culture" rules.

According to his son, Walter Igersheimer, who was studying in the UK at the time, unbeknownst to his father, his mother had applied for United States visas under the quota system. Her application was successful. In 1939, the Igersheimers went to the States on a lecture tour. While they were in America, the war broke out in Europe. Igersheimer and his wife could not easily leave. Friends in the Boston area encouraged him to stay and open an office. Joseph Igersheimer took all necessary tests and passed each and every one on his first try. With license to practice in hand, he opened an office $^{71}$.

Igersheimer started publishing books as early as 1919. By the time he went to Tufts College in Boston, he had no fewer than ten books in print. On the other hand, he started publishing papers in 1904. One page of references is followed by five others in his Tufts application, all just as fully loaded with references to papers published. He continued to publish during his exile years as well, understandably not at the same rate. In retrospect, perhaps it had been a hard pill to swallow for so eminent a scholar to have to accept the lowly title of Assistant Professorship appointment at Tuft's Medical School, but it was an appointment in his field and it was in the United States and his life would be safe. Once again, he prospered, reaching even greater heights. In time, Tufts College had recognized its "error" and Igersheimer was asked to act as Head of Ophthalmology, since the original had been drafted. He did so and, after the war, stayed on at Tufts as a full Professor ${ }^{32}$.

Sixty-five years after offering an Assistant Professor position to a great scholar and eminent practitioner who was also a superb teacher and practitioner, but under great duress, Tufts University had the following to say on its website:

In the 1930s and 1940s, the Departments of Medicine at both Tufts and the New England Medical Center were enhanced by the addition of a number of distinguished physicians who had fled Germany, including Drs. Siegfried Thannhauser, Gerhard Schmidt, Heinrich Brugsch, Joseph Igersheimer, and Alfred Hauptmann. The department was further strengthened by the arrival of Drs. Edwin Astwood, William Dameshek and William Fishman. After Dr. Samuel Proger was named professor and chair at the school and physician-in-chief at the New England Medical Center in 1948, he further strengthened the department at Tufts

70 İstanbul University Rectorate Personnel Department File Nr: 4109/111. From the Minister of Education to the President of İstanbul University, May 12,1939. This was on the eve of Germany's invasion of Poland.Turkey though neutral had good relations with Germany. The émigré community in Turkey was understandably concerned for their own safety in Turkey. The region Igersheimer wanted to work in is closest to Palestine. Were Turkish government members concerned that he might bolt? Perhaps.

71 Igersheimer's son, Walter, personal communication, August 21, 2005. 
by recruiting a number of outstanding faculty members, among them, Drs. Marshall Kaplan, Jerome Kassirer, Herbert Levine, Seymour Reichlin, Robert Schwarz, William Schwarz, and Louis Weinstein. ${ }^{72}$

At all times, Igersheimer was thankful to Turkey for what she had provided for him during the time of his greatest need. After becoming well established in America's ophthalmology ranks, Igersheimer continued to make contributions to its Turkish counterpart in various ways. Among these ways was the publishing of articles as is shown in Turkish medical journals.

Igersheimer's life was saved because Turkey needed his expertise. In turn, he did much for Turkey. According to Igersheimer's son, Walter, a retired Yale University Clinical Professor of Psychiatry, the family had never practiced the Jewish religion. Walter tells the story that, in 1917, Joseph Igersheimer was called in to see Germany's Minister of Health. At the meeting, he was offered the position of Chief of Ophthalmology at the University of Rostock, then the world's most renowned ophthalmology research centre. Igersheimer was clearly impressed and flattered by the offer. However, he did not accept it, as it was conditional on changing his religion ${ }^{73}$.

"This man was a genius and great humanist caught in the web of a mad historical period. One great love that Joseph had was teaching. ... [W]ith his modesty, gentleness, and quiet dignity intact, he came to the United States, a man not destroyed by man's inhumanity to man. There is true hope for an eventual world of peace if some are so capable of proving the nobility of man." 74 And in his own words:

No matter how beastly some human beings are capable of behaving, we must always remember that we must not act like animals. ${ }^{75}$

\section{Concluding remarks}

Fritz Neumark, an economist and one of the émigrés observed that:

... although in the years following 1933 the number of German-speaking refugees in other countries, especially in the United States, far exceeded those in Turkey, in no other place was the relative significance of German refugees ${ }^{76}$ as great as it was in Turkey, and nowhere else did their work leave as permanent an impact. ${ }^{77}$

72 http://dl.tufts.edu/view_text.jsp?urn=tufts:central:dca:UA069:UA069.005.DO.00001\&chap ter=D00020. Viewed March 1, 2006.

73 Personal communication, August 11, 2005.

74 Sloane 1969, $174 \mathrm{f}$.

75 Sloane $1969,174 \mathrm{f}$.

76 Because Turkey was a neutral nation throughout 1933 to almost 1945, the émigrés were being used as conduits of communication between friends, colleagues, and relatives left behind and those in the free world. See Reisman 2007c.

77 Neumark 1980, 8 f. 
Juxtaposition of the treatment of such intellectual treasure in Germany, compared to Turkey, along with the interwar anti-Semitic hiring bias in America's academe ${ }^{78}$, illuminates the shaping of our own scientific and cultural present and future ${ }^{79}$. Never before or since has the higher education sector of any country experienced a qualitative transformation of such proportions in so short a time frame. One country's great loss was another country's monumental gain and a third country's benefits delayed. This paper offers yet another "story" to "create a context of origin, that the people may not live alienated from their ancestry and in ignorance of the events that have given shape to their present" $"$.

Followed by two generations of indigenous talent, Turkey can now rightfully claim to have a modern system of higher education boasting some 72 public and private universities, many on par with what is available in the countries of the European Union and the United States. Memories of the émigré professors and the appreciation of their contributions to Turkey's modernization linger on in that country and among the educated Turkish Diaspora.

Recording and discussing significant episodes in history clearly precedes teaching of the same. However, this significant chapter in twentieth century history and its impact on Turkey's higher education seems to have fallen beyond the horizons of most historians ${ }^{81}$. Historians are too often unaware of this significant chapter in twentieth century history in general and its impact on Turkey's higher education in particular. Nor are historians aware of the level of intellectual capital saved from extinction, nurtured while in exile, and kept in escrow to set new paradigms in western science. There are two sides of remembering. Without question it is necessary not just to remember the Holocaust and to let the world know who was responsible for what crimes. It is a much greater obligation to survivors of the Holocaust, like

78 Another little known fact is how hard Albert Einstein has worked between 1933 and 1945 to find a safe haven for Jewish intellectuals at risk. Yes he was involved in persuading the Turkish government to accept some of them to teach in Turkey even if it meant at no pay. See Reisman 2007b.

79 In his memoir, Fritz Neumark, one of the émigré economists observed that "although in the years following 1933 the number of German-speaking refugees in other countries, especially in the United States, far exceeded those in Turkey, in no other place was the relative significance of German refugees as great as it was in Turkey, and nowhere else did their work leave as permanent an impact." (Neumark 1982,8f.)

80 "The image of Turkey in present-day Germany is determined by the so called 'Gastarbeiter" - foreign labourers, and 'mainly negative"' (Staudenmaier 1985), while in Turkey "Germany is regarded as a country in which people for political and religious reasons are being persecuted" (Müller 1998).

81 See Reisman 2007a. 
this author, to make sure that, irrespective of motivations, acts of humanity during this dark age are recorded, known, and taught.

Lastly the History and Mission statements as posted on the web by the original three Turkish universities document the prevailing national pride in the legacy that was left by the émigré professors ${ }^{82}$. Many testimonials to this legacy can be found in Turkey. Among these is one by Parliamentarian Onur Öymen"83: "A number of German professors with high reputations in their own countries participated in major reform projects in Turkey besides their teaching activities. For example, Andreas $S c h w a r z$ from Freiburg made an important contribution to the adoption of western laws in Turkey in 1930s."

\section{Bibliography}

Akar, Nejat, Anadoluda bir Çocuk Doktoru. Ord. Prof. Dr. Albert Eckstein. Genişletilmiş 2. Baskl (Ankara 2003)

- "Albert Eckstein: a pioneer in pediatrics in Turkey", Turkish Journal of Pediatrics 46 (2004) 295-297

- IA. Can, Anadolu'da 15 yil/15 years in Anatolia with Ord. Prof. Dr. Albert Eckstein (Ankara 2005)

Anonymous, "Haberler", Tip Dünyası (VII) 3 (1934) 2412

Ash, Mitchell G./Alfons Sollner (eds), Forced Migration and Scientific Change: Emigré GermanSpeaking Scientists and Scholars After 1933 (Cambridge 1996)

Bahadir, O. S./H. H. G. Danisman, "Late Ottoman and Early Republican Science", in: Gürol Irzik/Güven Guzeldere (eds), Turkish Studies in the History and Philosophy of Science (Berlin/New York 2005) 290

Bentwich, N., The Rescue and Achievement of Refugee Scholars: the Story of Displaced Scholars and Scientists, 1933-1952 (The Hague 1953)

Burk, Lâle Aka, "An Open Door: German Refugee Professors in Turkey”, in: Peter I. Rose (ed.), The Dispossessed - An Anatomy of Exile (Amherst MA 2005) 235-257

Fermi, Laura, Illustrious Immigrants (Chicago 1968)

Igersheimer, Josef, "Keratoplastik hakkında”, Türk Tip Cemiyeti Mecmuası V(3) (1988) 68-69

Ihsanoglu, Ekkmeleddin, "The Medreses of the Ottoman Empire", Publication 4055, Foundation for Science, Technology and Civilisation (Manchester 2004)

Kazancıgil, A./I. Ortaylı/U. Tanyeli, "Türkiyenin Yabancıları", Cogito (Istanbul: Yapı Kredi Yayınları, Üç aylık düşünce dergisi, Sayı:23, Yaz, 2000) 119-132

Langhoff, Wolfgang, Rubber Truncheon (New York 1935)

Liebermann-Meffert, Dorothea/M. Rossetti, “The 100th birthday”, Chirurg 67(10) (1996) 10531059

Loevy, H. T./A. A. Kowitz, "Alfred Kantorowicz, Pediatric Dentistry Innovator”, Journal of Dentistry for Children 60 (1993)

Moll H., "Emigrierte deutsche Pädiater: Albert Eckstein, Werner Solmitz", Monatsschrift für Kinderheilkunde 143 (1955) 1204-1207

Müller, H., "German Librarians in Exile in Turkey, 1933-1945", Libraries \& Culture 33 (1998) 294-305

82 Reisman 2006, 471-473.

83 A speech at a Seminar in Berlin, July 19, 2003. Obtained from <http://www.onuroymen.com/ docs/konusma37.doc> on September 10, 2005. 
Namal, Arin, Zwischen Emigration aus NS-Deutschland und Ankunft in Palästina bzw. Israel: Jüdische Wissenschaftler an der Universität Istanbul, Paper presented at: Medizin und Judentum, 8. Medizinhistorisches Kolloquium, Dresden, September 7./8. 2005, http://www. stiftung-sozialgeschichte.de/sozgeschonline/Emigration_Tuerkei.htm

- /Arnold Reisman, Joseph Igersheimer, Ophthalmologist and Visionary: his Contributions in Exile and Beyond (July 19, 2005), Paper available at http://ssrn.com/abstract=764426

- IArnold Reisman, "A Tale of Three Medical Researchers Saved by Turkey from Nazism. They went on to impact healthcare delivery in Turkey, Israel, and the USA", (forthcoming)

Neumark, Fritz, Zuflucht am Bosporus: Deutsche Gelehrte, Politiker und Künstler in der Emigration 1933-1953 (Frankfurt 1980)

- Boğaziçine Sı̆̆ınanlar, translated by Şgefik Alp Bahadır (Istanbul 1982)

Nissen, Rudolf, Helle Blätter, dunkle Blätter; Erinnerungen eines Chirurgen (Stuttgart 1969)

Reisman, Arnold, Turkey's Modernization: Refugees from Nazism and Atatürk's Vision (Washington DC 2006), http://www.newacademia.com/turkeys_modernization/

- "Turkey's Invitations to Nazi Persecuted Intellectuals Circa 1933: A Bibliographic Essay on History's Blind Spot" (2007a), working paper available on http://ssrn.com/abstract=993310

- "Jewish Refugees from Nazism, Albert Einstein, and the Modernization of Higher Education in Turkey (1933-1945)", Aleph: Historical Studies in Science \& Judaism 7 (2007b) 253-281, http://inscribe.iupress.org/doi/abs/10.2979/ALE.2007.-.7.253

- “German Jewish Intellectuals' Diaspora in Turkey: (1933-1955)", The Historian 69 (2007c) 450-478

Richter, R., "Ankara'dan Bir Mektup”, Cilt Doktoru, Yı1 5, Sayı 11, Kasım, 518 (1954)

Schwartz, Philipp, Notgemeinschaft. Zur Emigration deutscher Wissenschaftler nach 1933 in die Türkei (Marburg 1995)

Shaw, Stanford J., The Jews of the Ottoman Empire and the Turkish Republic (London 1991)

- Turkey and the Holocaust (London 1993)

Sloane, Albert E., "Biographical Sketch of Josef Igersheimer", Survey of Ophthalmology 14 (1969)

Staudenmaier, John M., Technology's Storytellers (Cambridge MA 1985)

Von Hippel, Arthur, http://vonhippel.mrs.org/vonhippel/life/AvHMemoirs9.pdf. Viewed October 7,2005

Widman, Horst, Exile und Bildungshilfe: Die Deutschsprachige Akademische Emigration in die Türkei nach 1933 (Bern 1973), translation: Atatürk Reformu (Ankara 1988)

Williams, M. O., "Turkey Goes to School”, The National Geographic Magazine 55 (January 1929) 94-108 